\title{
Sustainability Study of Government Procurement of Public Services in Guangzhou-A Perspective Based on the Resources Dependence of Social Work
}

\author{
Li Pan \\ School of Economics, Jinan University, Guangzhou, China \\ Email: pennypan156@163.com
}

Received 10 November 2015; accepted 14 December 2015; published 18 December 2015

Copyright (c) 2015 by author and Scientific Research Publishing Inc. This work is licensed under the Creative Commons Attribution International License (CC BY). http://creativecommons.org/licenses/by/4.0/

(c) (i) Open Access

\section{Abstract}

The recently prevalent government procurement of public services in China boasts a new form of government's provision of public service through the purchasing of social work from social organizations, a new measure of the transformation in governmental functions as well as an unprecedented opportunity for the development of social organizations. For the past few years, the phenomenon of a surge in the number of social work organizations and social work staff emerged right with the initiatives of energetically carrying out the purchase of public services by the government. Such efforts have presented the strong determination of the Chinese government in building a small government by streamlining administration and delegating part of the governmental power to social organizations. This paper was based on the 2012-2014 performance appraisal project of the Guangzhou municipal government's purchasing of public services and the project was carried out in the summer of 2015. During the process of the appraisal, several general problems hindering the sustainable development of government purchasing of public service have been observed. As Guangzhou is among the rank of pioneer cities in the conduct of the reform, it is representative and imperative to study the sustainability of government purchasing of public service. In 2012, Guangzhou local government started contracting out public service to the community social organizations to provide general family services and special services to community residents, since when integrated family service centers and special service centers were established as platforms to provide public social service in a city-wide range. Consequently, taking an example of the current rapid development of government purchase of the integrated family services and special services in Guangzhou, this paper puts up several proposals for the sustainable development of Guangzhou municipal government's procurement of public services on the perspective of social work's resource dependence. 


\title{
Keywords
}

\author{
Government Procurement of Public Services, Social Work, Sustainability, Integrated Family \\ Service Center, Guangzhou
}

\section{Introduction}

Government procurement of public services becomes a new approach for Chinese governments to furnish public services in the past few years. Seeking to change the way of providing public services which are originally in the range of government commitment through signing outsourcing contracts of public services with private nonprofit organizations and other social organizations, the Chinese municipal governments in certain metropolises have set out to explore the new way of public service provision, which has progressed to a new mechanism for Chinese local governments to provide public services. Led by pilot projects and implemented by local governments, this public service mechanism reform once exists and now even achieves successes in pioneer cities in China. Supporters for the implementation of government procurement of public services believe that such service delivery will introduce market competition mechanism to public service providers and as a result achieve progressive service performance. In the traditional natural monopoly position in China, direct government provision of public services will accompany with inefficient usage of funds, agency personnel expansion and insufficient utilization of limited public resources. Compared with the traditional internal production of public service, contracting out public service has an eminent advantage in the reduction of production costs and improvement in the quality of public services. The reasons are in comparable cases the two traditional mechanisms, bureaucracy and public enterprises, perform worse than the private sector due to the lack of public service producer competitors and competitive pressures in a single service provider market. Government procurement of public services reform in China is still in the early stages of development. Local governments buying public services from the social organizations have all encountered some difficulties and obstacles in the process. Therefore, the Guangzhou municipal government had made it clear to set the sustainability of government purchasing of public service as one of the performance appraisal indices in this year's performance appraisal project to evaluate the performance of public service delivered by social organizations during the year 2012 to 2014. Along with the transformation of government functions through procurement of public services are the rapid growth in the number of social organizations and the expansion of social work staff, which indicates that the government procurement of public services provides rich soil for the development and cultivation of social work professionals in social organizations. In addition, one of the goals of government purchasing of public services by the Guangzhou municipal government is to cultivate community social organization and community social workers. In recent years, the operation of integrated family services centers and special service centers in Guangzhou City is developing in full swing. The Integrated Family Service center and special service center function as platforms for social workers to deliver public service to the community, thus their operation is considered to be a direct manifestation of social workers' performance of social work. The author has participated in the Guangzhou Municipal Government's performance appraisal project of purchasing of Integrated Family Service Center to provide general family services and Special Service Center to provide special public services, during which a deep down research has been conducted and a profound understanding of the government purchasing of public service has formed. The survey on social work in Guangzhou and the interviews of social workers reflect a universal service issue that the resource constraints have influenced the effectiveness of the delivery of public services. Since any human activity is influenced by the interaction with different resources, resource constraints will inevitably affect the development process of social work and the government procurement of public services. As a result, this paper gives some advice on the responsibility of the governments and social workers in the Guangzhou Municipal Government purchases of public service project from the perspective of social work's resources dependence. Meanwhile, it puts forward some proposals in order to promote the sustainability of the Guangzhou municipal government procurement of public services.

\section{Literature Reviews}

In recent years, under the directing concept of building a service-oriented government, the local governments all 
over China made active reactions to transform their functions, vigorously carrying out the purchase of public service from the community social organizations with the aim of achieving the goal "small government, big society". The development of government procurement of public services has generated increasing researches on government procurement of public services which mainly focused on the model, scope, manner of government procurement of public service or the performance evaluation on government procurement of public services. Puju Wang (2009) presented us in his book the current development of government purchasing of public service in China and in other countries. He put forward insights on government procurement of public service worth of further discussion and improvement based on his analysis on the situation of government procurement of public services [1]. Ming Su, Xijin Ja (2010) have done a detailed explanation on the connotation meaning, subject, the status quo of government procurement of services. Moreover, Western governments' practice of procurement of public services has been implemented for a long time, now developing into a relatively matured model [2]. Additionally, foreign researchers Smith S. and Smith J. (1996) pointed out that the contract outsourcing and privatization does not necessarily produce a competitive market to improve the quality of public services because of a lack of competition in the service provider market and the insufficient funds provided by the government failing to cover costs together with the information asymmetry that present problems as well. His views are in line with the current situation in China and allow us to view government procurement of public services in a dialectical way [3]. Xueling Zeng (2014) took the integrated family service center in J Street, Guangzhou as an example, standing on the point of the relation between the government and social organizations, she analyzed the plight in the management of government procurement of public service and provided some proposals, in terms of the role of government, for the development of social organizations and the role of government in monitoring and assessment, etc [4]. Overall, scholars agree on that the practice of government procurement of public services is a contract which allows the government to cooperate with social organizations. Governments and social organizations in the contract are to play the role of public service supervisor and public service provider respectively, and it is stressed that the social organization should have independence in operating and avoids becoming the government's accessories. Scholars have also studied the process of buying and operating mechanisms of government procurement of public service. Through researches on the issue of government procurement of public services in China, they have made a lot of useful policy recommendations to promote a better development of government procurement of public services in China.

Similarly, social organizations being the other part of the contract of government procurement of public services, the development of social organizations and the construction of social work personnel have also become the research filed to scholars. Theoretical researches are mainly focused on the professionalization and specialization of social work, the methods of social work and the role social workers. Suju Lu (2005) focus on the ways to better specialize and professionalize social work in a traditional Chinese background of administrative process. She pointed out that the development of social work in mainland China is still in the initial stage of "semi-professional" or "quasi-professional", thus the development of social organizations needs support from government departments. Local governments should learn from the development experience of society organizations in developed western countries while achieving localization of Social Work Idea, and make it clear what duties and responsibilities of government departments are, in order to improve the professional education and training system to achieve social workers' specialization and professionalism [5]. Shuang Chen (2006), developed her research from the mission of a social worker and maintained that the professional social work plays an crucial role in protecting the rights and interests of vulnerable groups and is able to act as a supplement to government management. Hence social workers should act as safeguards of rights of vulnerable groups and in the process play the following roles: service providers to solve specific problems; supporters to help vulnerable groups gain self-reliance; advocates for vulnerable groups to take reasonable actions; managers to promote social work standardization and efficiency; coordinators to mobilize and integrate social resources [6]. Yaping Wang (2009) explained the role of social workers within a civil society analytic framework. He believes that the government does not have the ability to provide a variety of professional services under the administrative system, and therefore social workers act as the complement, under the framework, to the separate functions of government. Social workers should target the disadvantaged as service object, while the government should regulate the development of social workers. Since the social workers can engage in all areas of social services, the term of social workers is a very broad concept, but analyzing social workers in the civil community framework is exactly in accordance with the analysis of social work in government procurement of public services in Guangzhou [7]. Qun Zeng (2007) analyzed the relationship between the government and social organizations from 
complementary strengths advantage between the government and social organizations. He pointed out that the non-profitability of community social organizations can enable the Government to cooperate with social organizations and help to prevent the government's failure and the market failure. However, the non-profit organization presents a "voluntary failure" phenomenon, namely the non-profit organization cannot produce resources to achieve enough service output, so social work organizations cannot function independently without the support and supervision of the government [8].

However, both the government procurement of public services and the development of social work as a specialized profession in China are still new things. Research on the sustainable development of social organizations and how to promote sustainable government procurement of public services is still relatively scarce in the theory world. Now that the social worker's job is the commodity in the government procurement of public services project, its quality determines the demand of buyers. The resource-dependence nature and the lack of service resources paradox manifested by social organization in Guangzhou Municipal Government procurement of public services project is thought-provoking, and it is necessary to give sustainability policy recommendations from the perspective of resource dependence of Social Work in the Guangzhou municipal government procurement of public service practice.

\section{The Practice of the Guangzhou Municipal Government's Procurement of Public Services}

The Practice of the Guangzhou municipal government procurement of public services can be dated back to 2007 and it has now been carried out for many years. The process of the development of government purchasing of public service has witnessed the pilot exploration, gradually promotion and standardization in general. Guangzhou municipal government procurement of public services aims at meeting the needs of society. In the form of open tender to the public and through a fair competitive bidding eligible social organizations are chosen to make a contract with the government. Those social work institutions who have gained the bids are given the right and funds to provide public service in corresponding Integrated Family Service Center or Special Services Center. Up until 2014, the Guangzhou municipal government has invested 1.1 billion Yuan of financial funds in purchasing the integrated family service projects and has established a total number of 171 Integrated Family Service Centers, realizing the $100 \%$ coverage of the service center in all the city's streets. At present, Guangzhou government has purchased 22 special social work services; special services covered a scope from the field of basic care services, youth services, community volunteer services, community correction service, medical social work service, and disability rehabilitation services to immigrant service, social services for rural, remote workers, national integration services and other special services. In 2014 the financial investment to government procurement of public services reached a total of about 330 million Yuan, creating a total of 3800 jobs, including 2500 professional social work jobs and the number of social service organizations that are eligible to undertake the public service provision has amounted to 267.

Overall, the Guangzhou municipal government procurement of public services is developing fast. The Integrated Family Service Center and Special Service Center have been playing insignificant roles in providing services to the needy families, the youth, the elderly and other groups; and have gained achievement in helping vulnerable groups to resolve social conflicts, coordinating social relations, easing stress and conflict, integrating social resources, encouraging social potential, restoring and enhancing social functions. They are developing towards the ultimate goal to promote happy families, happy communities and building a harmonious society.

\section{Analysis of the Effect that Social Work's Resources Dependence Have on the Sustainability of Government Purchasing of Public Services}

According to the resource dependence theory, an organization must rely on resources in order to survive. But, in fact, an organization cannot have all the resources it needs, so in order to obtain these resources, it must interact with those organizations in possess of these resources. Social organizations also need the support of resources from other organizations. Apart from that, the quick development in the number of social work organization involved in the bidding for the project of government procurement of public service in Guangzhou is a sudden emergence in response to the government's such practice. Thus the development of social organizations is far from mature, and they need the support of resources from all parties. In the project of government procurement of public services, if the organization does not survive, it will for sure lead directly to the failure of government 
procurement of public services.

According to the survey conducted among those social workers working in the Integrated Family Service Center and Special Service Center in Guangzhou, at present, inadequate resources in providing social work included mainly the financial resources, policy resources and human resources.

1) Financial Resources

Financial resources are a reflection of the strength of an organization. The lack of financial resources in a social work organization has mainly a negative effect on the operation of the social organization. Site investigation shows that the lack of funds has hampered the functioning of the Integrated Family Service Center and the Special Services Center. Currently, in view of the development of social work organizations involving in the government procurement of public service project, the social organizations that in charge of the Integrated Family Service as well as special services is almost entirely dependent on the financial investment from the government. However, the development of social work is a long process; its dependence on a single administrative support from the government is not the best development path for social work organizations. In the interviews with the social workers, many manager in charge of social work organizations and front-line social workers admitted that "the current source of funding is solely government grants, there is no other source in that integrated family service is very difficult to raise social funds." Meanwhile, the amount of financial funds appropriated by the Guangzhou municipal government, for the past three years, to each family service centers has maintained at 2 million Yuan unchanged. The financial situation was worsening by the fact that government funding isn't always delivered in a timely manner. If the organization cannot be self-financing, once the capital chain disrupted, the operation of social organizations will also be interrupted.

2) Policy Resources

Since Guangzhou municipal government started the practice of supporting the development of social work by purchasing public service from social work organizations in 2007, the government has introduced 22 thematic files on social work development and on government procurement of public service. These documents covering financial management, service purchasing management, service provision management, and service monitoring management, have basically formed a relatively clear and complete institutional framework. While there is still a lack of official documents with respect to support the development of social work and the expansion of social work sector, which makes it difficult to carry out social work in Guangzhou City. Since social work has its appearance only in recent years and it is closely attached to the government purchasing of public service, it is the responsibility of the Government to give policy support to the social organizations. After all, according to the history of China's socialist economic system, the government occupies the vast majority of resources. Government purchases social work in order to provide better services to the people, but now the service provided by the Integrated Family Service Centers and the Special Service Centers in Guangzhou is not as good as expected. Also there is a general phenomenon reflected by social workers when they offer to provide services to some residents, they sometimes will be denied as they are suspected of being fraudsters. It caused a great damage on social workers' career confidence. The fact that residents of the community do not know and do not trust the social workers increase the difficulty for social workers to carry out the service. Therefore, the lack of policy will also affect the sustainability of the Guangzhou municipal government procurement of public services.

3) Human Resources

Human resources is composed of both the quantity and the quality of human, from the organizational perspective, human resource is the sum of staff members and their intelligence, knowledge, skills, and their strength in coordination and innovation. Social workers are the most important human resource to the social organization, for they command and take control of the available resources in the organization. Since those social work organizations involved in the Guangzhou municipal government procurement of public services are newly developed agencies and are in their early developing phase, they are facing problems of internal imperfections such as financial management imperfection, quality control imperfection and other issues, while they are also suffering from the lack of professional social work management personnel, supervisory personnel and social work personnel. The Investigation conducted among those social organizations in Guangzhou has shown that many social workers are not professional graduates from social work or related majors. The vast majority of front-line social workers are recent university graduates, a group lack of social work experience in professional services. And they are more likely to experience ethical dilemmas, thus result in social work staff's frequent mobility. In Guangzhou, for the social work organizations have difficulty in attracting and retaining talented people to social work, many social workers who are not originally major in social work are recruited in a way that forcing them 
to get a certificate of social workers to meet the staffing requirements set by the government. Hence social work organization gives admission to non-professionals with a separate social work permit to fill the staff vacancy. The social work itself is a very professional work, precisely because the government cannot provide such professional public services. It is recommended that the government resort to the way of purchasing of professional social workers to provided public services. On the contrary, from the view of staff qualifications in the government procurement of public service in Guangzhou, there is still distance from the professional. The professionalism of social workers determines the professionalism of public service purchased by the government. As service providers, social workers directly determine the form of government procurement of public services as well as the quality of public service. So human resources also affect the sustainability of government procurement of public services.

\section{Conclusion and Recommendations}

Social work organizations involved in Guangzhou municipal government procurement of public service have shown their dependence on resources and their current lack of resources, such phenomenon can be attributed to the following aspects: 1) Social workers for providing integrated family service and special services fail to effectively leveraging social resources; 2) The Government doesn't provide enough policy support in the process of procurement of public services; 3) Social Work industry is inexperienced. The instability of this industry causes the loss of talent. To conclude, the difficulty to get access to resources in these three areas lies in the low recognition of the social work as a profession, whereas the recognition is built on the acceptance of social workers by the government, social and social workers themselves. The recognition by the society is gained from the professional and effective services provided by social workers. Therefore, to resolve the plight of social work resources dependence, changes should be taken from the government and social workers themselves. The Government should improve policy guidance; make it clear of the status, obligations and responsibilities of social workers. It should also introduce an incentive mechanism to stabilize the management team and retain the firstline social workers in social work industry. With this, the government should also make an effort to increase its advocate of social work. Social workers should also focus on improving their expertise of providing service and capability of linking resources in practice and through experiences. They should also realize their role as social workers. Only with the concerted efforts of governments and social workers, will the integrated family services and the special services become professional services brand and generate social effects. And social work organizations are possible to be able to mobilize other community resources and achieve the integration of multiple resources to promote the sustainable development of Guangzhou municipal government procurement of public services.

\section{References}

[1] Wang, P.J., Lester, M. and Meng, S.L. (2010) Public Service of Government Purchases to Social OrganizationsChina and Global Experience Analysis. Beijing University Press, Beijing.

[2] Su, M., Ja, X.J. and Sun, J. (2010) Research on Chinese Government Procurement of Public Services. Fiscal Studies, 9-17.

[3] Smith, S. and Smith, J. (1996) Contracting for Services in a Decentralized System. Journal of Public Administration Research and Theory.

[4] Zeng X.L. and Chen, J.D. (2014) Government and Social Organizations: A Case Study of Integrated Family Service Center in J Street, Guangzhou. Seek, 277-296.

[5] Lu, S.J. (2005) A Study on the Professionalism and Specialization of Social Workers to the Status Quo. Exploring Education Development, 48-51.

[6] Chen, S.Q. (2008) A Preliminary Study of Collected Essays on Government Purchase of Social Work Service. Fiscal Studies, 51-54.

[7] Xue, X.Y. (2007) Cognitive Thinking on the Role of Community Social Worker. Chinese Society Guide, 38-39.

[8] Zeng, Q. (2007) Partnership between Governments and Social Organizations. Chinese Society Guide, 1. 